\title{
STUDI KOMPARASI TINGKAT KEBISINGAN PADA WAKTU BERBEDA DI SEKOLAH DASAR NEGERI MELAYU 2 BANJARMASIN
}

\author{
Agus Dian Mawardi', Saidah Tunnoor ${ }^{2}$ \\ Dosen FKIP Universitas Achmad Yani Banjarmasin ${ }^{1,2}$ \\ Jl. A. Yani Km.5,5 Komplek Stadion Lambung Mangkurat Banjarmasin \\ E-mail: agusdm@uay.ac.id
}

\begin{abstract}
The research objective was to determine the Noise Level and the Difference in Noise Level at Different Times in SDN Melayu 2 Banjarmasin. The object of research is "noise levels at different times". The sampling technique used purposive sampling. The sample in this study is a classroom. The research variable consisted of the $\mathrm{X}$ variable, namely the time of measurement, namely $08.00,10.00 \mathrm{Wite}$, and $12.00 \mathrm{WIB}$. The variable $\mathrm{Y}$ is the noise level at each measurement time. Comparative study using the one-way ANOVA approach or the F-test (Fisher Test) assisted by the application of SPSS version 23. The results of the study were significant differences at different noise levels at 08.00, 10.00, and 12.00 Wite. Generally, the noise level at SDN Melayu 2 Banjarmasin has passed the $55 \mathrm{~dB}$ threshold. The highest level of noise occurred at 08.00 Wite with an average of $66.26 \mathrm{~dB}$, followed at 10.00 Wite with an average of $62.79 \mathrm{~dB}$, and the lowest at 12.00 Wite with an average value of $60.36 \mathrm{~dB}$.
\end{abstract}

Keywords: Noise Level; Comparison; Public Elementary School; Banjarmasin

\begin{abstract}
ABSTRAK
Tujuan penelitian ingin Mengetahui Tingkat Kebisingan dan Perbedaan Tingkat Kebisingan pada Waktu Berbeda di SDN Melayu 2 Banjarmasin. Objek penelitian adalah "tingkat kebisingan pada waktu yang berbeda". Teknik sampling menggunakan Purposive Sampling. Sampel dalam penelitian ini adalah ruangan kelas. Variabel penelitian terdiri dari variabel $\mathrm{X}$ adalah waktu pengukuran, yaitu pukul $08.00,10.00$ Wite, dan 12.00 Wite. Variabel Y adalah Tingkat kebisingan pada masing-masing waktu pengukuran. Penelitian komparasi dengan pendekatan ANOVA satu jalur atau uji-F (Fisher Test) dibantu apllikasi SPSS versi 23. Hasil penelitian adanya perbedaan yang signifikan pada taraf kebisingan yang berbeda di jam 08.00, 10.00, dan 12.00 Wite. Taraf kebisingan di SDN Melayu 2 Banjarmasin secara umum sudah melewati batas ambang yang ditetapkan sebesar $55 \mathrm{~dB}$. Taraf kebisingan tertinggi terjadi pada jam $08.00 \mathrm{Wite}$ dengan rata-rata $66,26 \mathrm{~dB}$, disusul pada jam 10.00 Wite dengan rata-rata $62,79 \mathrm{~dB}$, dan terendah pada jam 12.00 Wite dengan nilai rata-rata sebesar 60,36 dB.
\end{abstract}

Katakunci: Tingkat Kebisingan; Komparasi; Sekolah Dasar Negeri; Banjarmasin

\section{PENDAHULUAN}

Luas Kota Banjarmasin 98,46 km persegi atau 0,26\% dari luas wilayah Provinsi Kalimantan Selatan. Kota Banjarmasin terdiri dari 5 kecamatan dengan 52 kelurahan dengan jumlah penduduknya sebesar 700.869 jiwa berdasarkan data dari BPS Kalsel tahun 2018. Artinya sebagai kota Banjarmasin dihuni kurang lebih 7120 an per km persegi. Seperti permasalahan kota lain, Banjarmasin juga mengalami perubahan pembangunan, sehingga bertampak kepada kepadatan lalu lintas. 
SDN Melayu 2 Banjarmasin yang terletak di jalan veteran dan termasuk berdedakatan dengan kawasan komersial Dua Mall dan padat penduduk tentunya mempunyai permasalahan tersendiri jika dilihat dari sudut pendidikan terutama mengenai dampak polusi suara atau kebisingan di sekitar sekolah.

Menurut WHO (Chandra, 2014:172) kebisingan ialah salah satu suara yang tak diharapkan, WHO mengartikan kebisingan ialah bunyi atau suara-suara yang tak dikehendaki sehingga mengganggu ataupun membahayakan kesehatan. Contohnya aktivitas lalu lintas kendaraan, truk, ambulan, dan lain sebagainya. Sekolah sebagai lembaga pendidikan formal juga tidak luput dari efek ancaman kebisingan yang terus menerus terjadi akibat aktivitas lalu lintas kendaraan yang padat setiap harinya. Sehingga masalah mengenai pengaruh kebisingan pada sebuah bangunan pendidikan tidak dapat dikesampingkan begitu saja, terutama untuk meningkatkan kulitas pendidikan di Indonesia.

Menurut Permenkes RI No.718/Meen.Kes/Per/XI/1987, baku tingkat kebisingan pada zona pendidikan adalah minimum yang dianjurkan sebesar $45 \mathrm{~dB}$ (Desibel) dan maksimum yang diperolehkan sebesar $55 \mathrm{~dB}$ (Desibel). Dampak kebisingan terhadap proses belajar antara lain gangguan berkomunikasi, gangguan terhadap pendengaran, serta konsentrasi.

Menurut Halil (2015:54) mengatakan bahwa bangunan sekolah yang berdekatan dengan jalan raya berdampak sangat rawan bising yang dapat mempengaruhi aktivitas kegiatan belajar siswa/murid di dalam ruangan kelas. Beberapa hasil penelitian mengungkapkan bahwa semakin tinggi tingkat bising diruang kelas, maka semakin rendah konsentrasi belajar siswa pada kelas tersebut dan sebaliknya semakin rendah tingkat kebisingan ruang kelas, maka akan semakin tinggi konsentrasi belajar siswa.

Berpijak dari kenyataan empiris yang ada di lapangan, maka perumusan masalah dalam penelitian ini mempertanyakan berapakah tingkat kebisingan di SDN Melayu 2 Banjarmasin? Dan adakah perbedaan tingkat kebisingan pada waktu berbeda di SDN Melayu 2 Banjarmasin?

Adapun tujuan yang ingin diraih adalah ingin Mengetahui Tingkat Kebisingan di SDN Melayu 2 Banjarmasin dan kedua ingin Mengetahui Perbedaan Tingkat Kebisingan pada Waktu Berbeda di SDN Melayu 2 Banjarmasin.

Urgensi penelitian ini yaitu ingin memberikan informasi Tingkat Kebisingan di SDN Melayu 2 Banjarmasin dab agar dapat memberikan data tentang Perbedaan Tingkat Kebisingan pada Waktu Berbeda di SDN Melayu 2 Banjarmasin sehingga dapat membuat pengelolaan pada proses pembelajaran yang lebih baik.

\section{METODE PENELITIAN}

Rancangan penelitian ini merupakan penelitian yang menggunakan pendekatan komparasional. Penelitian Komparasi menurut Arikunto (2014:6-7) termasuk dalam penelitian deskriptif. Kata 'komparasi' dalam bahasa lnggris comparation, yaitu perbandingan. Makna dari kata tersebut menunjukkan bahwa dalam penelitian ini peneliti bermaksud mengadakan perbandingan kondisi yang ada di dua tempat, apakah kedua kondisi tersebut sama, atau ada perbedaan, dan kalau ada perbedaan, kondisi di tempat mana yang Iebih baik dari hasil dari penelitian ini.

Selanjutnya menurut Sudijono (2014:275) mengatakan bahwa Teknik Analisis Komparasional, yaitu: salah satu teknik analisis kuantitatif atau salah satu teknik analisis statistik nferensial iyang dapat digunakan untuk memguji hipotesis mengenai tentang ada 
tidaknya perbedaan antar variabel yang sedang diteliti. Jika perbedaan itu memang ada, apakah perbedaan itu merupakan perbedaan yang berarti atau meyakinkan (signifikan), ataukah bahwa perbedaan itu hanyalah secara kebetulan saja (by chance).

Dalam penelitian ini melakukan pengukuran tingkat kebisingan pada ruang belajar yang sudah ditentukan/terpilih untuk dilakukan pengukuran dengan alat sound level pada tiga waktu yang berbeda, yaitu pukul 08.00 Wite, 10.00 Wite, dan $12.00 \mathrm{Wite}$. Lama pengukuran tingkat kebisingan rencananya selama 5 (Lima) menit sebanyak 30 (tiga puluh) kali pengukuran di sekolah. Analisa data menggunakan Anova satu jalur (One Way Anova).

Lokasi penelitian di Sekolah Dasar Negeri Melayu 2 Kecamatan Banjarmasin Timur, Kota Banjarmasin, Provinsi Kalimantan Selatan.

Waktu penelitian direncanakan selama 8 (delapan) bulan dimulai dari penandatanganan kontrak, revisi pembuatan proposal sampai termasuk pembuatan laporan hasil penelitian.

Yang menjadi variabel dalam penelitian ini adalah tingkat kebisingan sekolah pada waktu yang berbeda. Dalam penelitian ini pengukuran kebisingan dilakukan pada jam 08.00 Wite, 10.00 Wite, dan 12.00 Wite di tempat yang ditentukan peneliti.

Variabel penelitian ini dapat digambarkan sebagai berikut:

$$
\begin{aligned}
& \mathrm{X}_{1} \rightarrow \mathrm{Y}_{1.1,1.2, \ldots 1 . \mathrm{n}} \\
& \mathrm{X}_{2} \rightarrow \mathrm{Y}_{2.1,2.2, \ldots 2 . n} \\
& \mathrm{X}_{3} \rightarrow \mathrm{Y}_{3.1,3.2, \ldots 3 . \mathrm{n}}
\end{aligned}
$$

Jika variabel $\mathrm{X}$ adalah Jam pengukuran dan $\mathrm{Y}$ adalah Tingkat Kebisingan hasil pengkuran. Dimana:

$\mathrm{X}_{1}=$ Waktu pengukuran Jam 08.00 Wite, $\mathrm{Y}_{1}=$ Tingkat kebisingan pada Jam 08.00 Wite, $\mathrm{X}_{2}=$ Waktu pengukuran Jam 10.00 Wite, $\mathrm{Y}_{2}=$ Tingkat kebisingan pada Jam 10.00 Wite, $\mathrm{X}_{3}=$ Waktu pengukuran Jam $12.00 \mathrm{Wite} \mathrm{Y}_{3}=$ Tingkat kebisingan pada Jam 12.00 Wite.

Objek penelitian adalah suatu variabel penelitian yang merupakan inti dari problematika penelitian (Arikunto, 2013:161). Objek dalam penelitian ini adalah "tingkat kebisingan pada waktu yang berbeda".

Subjek penelitian adalah benda, hal, atau orang tempat data untuk variabel penelitian dan yang dipermasalahkan (Arikunto, 2010:88). Adapun yang menjadi subjek dalam penelitian ini adalah Sekolah Dasar Negeri Melayu 2 Banjarmasin.

Populasi adalah wilayah generalisasi berdasarkan objek ataupun subjek yang mempunyai kualitas dan karakteristik tentunya yang ditetapkan oleh peneliti untuk dipelajari dan kemudian ditarik kesimpulannya (Sugiyono, 2017:117). Jadi populasi dalam penelitian ini yaitu sekolah SDN Melayu 2 Banjarmasin.

Menurut Sugiyono (2017:118) sampel adalah bagian dari jumlah dan karakteristik yang dimiliki oleh populasi tersebut. Teknik penarikan sampel yang digunakan dalam penelitian ini adalah Purposive Sampling dengan alasan agar tujuan penelitian untuk mengetahui kebisingan tercapai. Sampel dalam penelitian ini adalah ruangan kelas yang dekat dengan jalan raya.

Adapun langkah-langkah yang akan dilakukan dalam penelitian ini adalah: Persiapan, Kolekting data pendukung, Pengumpulan data, Pembuatan/tabulasi Data, Analisis Data dan Pembahasan, Penyusunan Laporan dan editing, Finishing dan penjilidan. Data penelitian didapat dari hasil pengukuran langsung setiap hari dan waktu serta tempat yang sudah ditentu. Data sekunder didapat dari dokumen sekolah untuk 
melengkapi data penelitian. Hasil pengolahan data akan dianalisa menggunakan pendekatan ANOVA satu jalur atau dengan nama lain uji-F (Fisher Test). Dalam perhitungan menggunakan apllikasi SPSS (Statistical Product and Service Solutions) versi 23. Adapun rumus yang digunakan sesuai pendapat Riduwan (2010:165) sebagai berikut:

$$
K R=\frac{J K}{\mathrm{dk}}
$$

\section{HASIL PENELITIAN DAN PEMBAHASAN Hasil Penelitian}

\section{a. Profile SDN Melayu 2 Banjarmasin Saat Penelitian}

SDN Melayu 2 Banjarmasin beralamat di Jl. Veteran RT.20 No.160 Kelurahan Melayu Kecamatan Banjarmasin Tengah Kota Banjarmasin Provinsi Kalimantan Selatan dengan Kode Pos 70232. Sekolah Dasar Negeri Melayu 2 Banjarmasin dapat dihubungi melewati telpon sekolah dengan nomor 0511-3267259. Sekolah Dasar Negeri Melayu 2 Banjarmasin berdampingan dengan salah satu gedung fakultas kedokteran Universitas Lambung Mangkurat (ULM).

Sekolah Dasar Negeri Melayu 2 Banjarmasin terdaftar pada tahun 1970 atas nama SDN Cemara, tahun 1985 berubah nama menjadi SDN Melayu 2 dan sejak tahun 2010 SDN Melayu 12 digabungkan ke SDN Melayu 2.

Berdasarkan Surat Keputusan (SK) Tim Penilai Badan Akreditasi Nasional Sekolah (BAN-S/M) Kalimantan Selatan tahun 2015 menetapkan SDN Melayu 2 memperolah Akreditasi Kualifikasi A (Amat Baik) Nilai 92 dan berlaku sampai dengan tanggal 31 Oktober 2020 Tahun Pelajaran 2019/2020.

Bangunan Permanen Tiga Lantai dengan Jumlah Ruangan 12 Ruangan yang terdiri: 1 Ruangan Kepala Sekolah, 1 Ruangan Guru, 1 Ruangan Perpustakaan, 1 Ruangan Aula, 3 Ruangan Laboratorium, 1 Ruangan Serbaguna, 1 Ruangan Musholla, 2 (bilik) WC Guru, dan 12 (bilik) WC Murid.

Berdasarkan hari orientasi observasi saat penelitian per 02 Juli 2020 dimana kondisi Sekolah Dasar Negeri Melayu 2 Banjarmasin dalam keadaan kondisi diberlakukannya Pembatasan Sosial Berskala Besar (PSBB) oleh pemerintah kota Banjarmasin akibat pandemi Covid-19. Saat itu pihak sekolah lagi mengadakan penerimaan siswa baru tahun ajaran 2020/2021.

Adapun data jumlah siswa di SDN Melayu 2 Banjarmasin tahun 2019/2020 setiap kelasnya dapat dilihat pada tabel 1 di bawah ini:

Tabel 1. Data Jumlah Siswa Di SDN Melayu 2 Banjarmasin

Tahun 2019/2020 setiap Kelasnya

\begin{tabular}{|c|c|c|c|c|}
\hline \multirow{2}{*}{ Kelas } & \multicolumn{3}{|c|}{ Jumlah Siswa (orang) } & \multirow{2}{*}{ Jumlah Rombel } \\
\cline { 2 - 4 } & Putra & Putri & Total & \\
\hline Kelas 1 & 15 & 19 & 34 & 2 \\
\hline Kelas 2 & 30 & 22 & 52 & 2 \\
\hline Kelas 3 & 17 & 24 & 41 & 2 \\
\hline Kelas 4 & 29 & 27 & 56 & 2 \\
\hline Kelas 5 & 27 & 24 & 41 & 2 \\
\hline Kelas 6 & 27 & 23 & 50 & 2 \\
\hline Jumlah & 145 & 139 & 284 & 12 \\
\hline
\end{tabular}




\section{b. Hasil Pengukuran}

Hasil pengukuran kebisingan pada jam berbeda dapat dilihat pada tabel di bawah ini:

Tabel 2. Hasil Pengukuran Kebisingan Pada Jam Berbeda

\begin{tabular}{|c|c|c|c|c|c|}
\hline \multirow{2}{*}{ No. } & \multirow{2}{*}{ Tanggal } & \multicolumn{2}{|c|}{ Waktu Hasil Pengukuran } & \multirow{2}{*}{ Remark } \\
\cline { 3 - 5 } & & 08.00 & 10.00 & 12.00 & \multirow{2}{*}{} \\
\hline 1 & 6-Juli-20 & 70.85 & 62.85 & 60.70 & \\
\hline 2 & 7-Juli-20 & 68.40 & 62.85 & 59.95 & \\
\hline 3 & 8-Juli-20 & 65.75 & 63.25 & 63.45 & \\
\hline 4 & 9-Juli-20 & 65.55 & 61.40 & 55.35 & \\
\hline 5 & 10-Juli-20 & 65.10 & 68.10 & 58.55 & \\
\hline 6 & 11-Juli-20 & 65.85 & 64.00 & 58.40 & \\
\hline 7 & 13-Juli-20 & 66.95 & 62.85 & 63.15 & \\
\hline 8 & 14-Juli-20 & 66.80 & 63.20 & 62.80 & \\
\hline 9 & 15-Juli-20 & 64.40 & 57.10 & 65.85 & \\
\hline 10 & 16-Juli-20 & 64.20 & 64.15 & 56.35 & \\
\hline 11 & 17-Juli-20 & 70.55 & 62.45 & 61.00 & \\
\hline 12 & 18-Juli-20 & 65.55 & 61.40 & 55.35 & \\
\hline 13 & 20-Juli-20 & 65.75 & 63.25 & 63.45 & \\
\hline 14 & 21-Juli-20 & 65.55 & 61.40 & 55.35 & \\
\hline 15 & 22-Juli-20 & 65.70 & 68.00 & 58.40 & \\
\hline 16 & 23-Juli-20 & 65.85 & 64.00 & 58.40 & \\
\hline 17 & 24-Juli-20 & 66.95 & 62.85 & 63.15 & \\
\hline 18 & 25-Juli-20 & 65.55 & 61.40 & 55.35 & \\
\hline 19 & 27-Juli-20 & 64.40 & 57.10 & 65.85 & \\
\hline 20 & 28-Juli-20 & 64.20 & 64.15 & 56.35 & \\
\hline 21 & 29-Juli-20 & 66.95 & 62.85 & 63.15 & \\
\hline 22 & 3-Agts-20 & 68.40 & 62.85 & 59.95 & \\
\hline 23 & 4-Agts-20 & 66.95 & 62.85 & 63.15 & \\
\hline 24 & 5-Agts-20 & 65.55 & 61.40 & 55.35 & \\
\hline 25 & 6-Agts-20 & 65.10 & 68.10 & 58.55 & \\
\hline 26 & 7-Agts-20 & 65.85 & 64.00 & 58.40 & \\
\hline 27 & 8-Agts-20 & 66.95 & 62.85 & 63.15 & \\
\hline & & & & \\
\hline
\end{tabular}


Jurnal Terapung : Ilmu - Ilmu Sosial , Vol. 2, No. 2, September 2020 ISSN: 2656-2928

\begin{tabular}{|c|c|c|c|c|c|}
28 & $\begin{array}{c}10 \text {-Agts- } \\
20\end{array}$ & 66.80 & 63.20 & 62.80 & \\
\hline 29 & $\begin{array}{c}11 \text {-Agts- } \\
20\end{array}$ & 64.40 & 57.10 & 65.85 & \\
\hline 30 & $\begin{array}{c}12 \text {-Agts- } \\
20\end{array}$ & 66.95 & 62.85 & 63.15 & \\
\hline & Rata-rata & 66.26 & 62.79 & 60.36 &
\end{tabular}

Secara umum hasil pengukuran memperlihatkan tingkat kebisingan rata-rata di sekolah dasar negeri melayu 2 banjarmasin pada jam 08.00 Wite sebesar 66,26 dB (desibel), pada jam 10.00 Wite menunjukan sebesar 62,79 dB dan jam 12.00 Wite sebesar 60,36 dB. Artinya, nilai kebisingan di Sekolah Dasar Negeri Melayu 2 Banjarmasin sudah di atas ambang level kebisingan Nilai Ambang Batas (NAB) atau baku mutu tingkat kebisingan untuk kawasan pendidikan yang diperbolehkan yakni sebesar $55 \mathrm{~dB}$. Nilai Ambang Batas (NAB) atau baku mutu tingkat kebisingan berdasarkan Baku Mutu Peruntukan Kawasan, yang diterbitkan oleh Menteri Lingkungan Hidup tahun 1996.

Tingkat kebisingan terendah pada jam 08.00 Wite terjadi pada tanggal 16 dan 28 Juli 2020 dengan nilai 64,20 dB. Tingkat kebisingan jam 08.00 Wite yang mendekati nilai rata-ratanya terjadi pada tanggal 14 Juli dan 10 Agustus 2020 dengan nilai 66,80 dB, sedangkan nilai tertinggi terdapat pada tanggal 6 Juli 2020 sebesar 70,85 dB.

Tingkat kebisingan terendah pada jam 10.00 Wite terjadi pada tanggal 15 dan 27 Juli 2020 dengan nilai 57,10 dB. Tingkat kebisingan jam 10.00 Wite yang mendekati nilai rata-ratanya terjadi 9 (sembilan) hari pada tanggal 6, 7, 13, 24, 29, Juli sampai dengan 3, 4, 8 dan 12 Agustus 2020 dengan nilai $62,85 \mathrm{~dB}$, sedangkan nilai tertinggi terdapat pada tanggal 10 Juli dan 6 Agustus 2020 sebesar 68,10 dB.

Tingkat kebisingan terendah pada jam 12.00 Wite terjadi pada tanggal 9, 18 dan 21 Juli 2020 dengan nilai 55,35 dB. Tingkat kebisingan jam 12.00 Wite yang mendekati nilai rata-ratanya terjadi pada tanggal 7 Juli dan 3 Agustus 2020 dengan nilai 59,95 dB, sedangkan nilai tertinggi terdapat pada tanggal 15 dan 27 Juli serta tanggal 11 Agustus 2020 sebesar $65,85 \mathrm{~dB}$.

Hasil pengukuran dapat dilihat pada gambar 1 berikut ini:

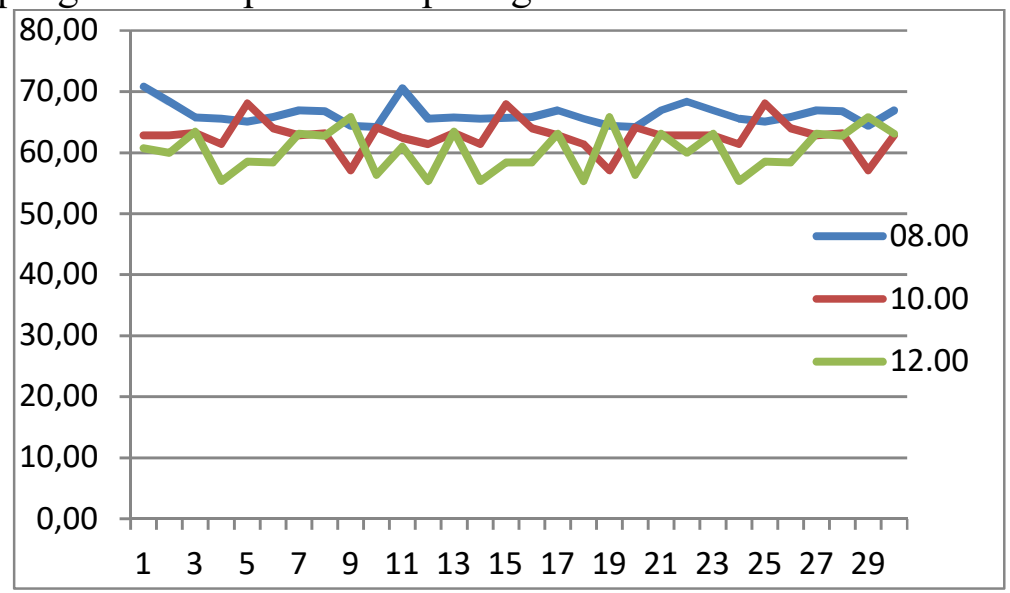

Gambar 1. Grafik Garis Hasil pengukuran pada Jam Berbeda

\section{Hasil Pembahasan}

Setelah melakukan pengukuran tingkat kebisingan pada jam yang berbeda di dalam ruang yang sudah dientukan, selanjutnya dilakukan analisa uji dengan menggunakan 
statistik. Adapun hasil perhitungan analisa statistik dengan menggunakan aplikasi SPSS release 23 dapat dilihat pada tabel di bawah ini:

Tabel 3. Hasil Descriptif Output SPSS 23

Descriptives

Kebisingan

\begin{tabular}{|c|c|c|c|c|c|c|c|c|}
\hline & \multirow{2}{*}{$\mathrm{N}$} & \multirow{2}{*}{ Mean } & \multirow{2}{*}{$\begin{array}{c}\text { Std. } \\
\text { Deviatio } \\
\mathrm{n}\end{array}$} & \multirow{2}{*}{$\begin{array}{l}\text { Std. } \\
\text { Error }\end{array}$} & \multicolumn{2}{|c|}{$\begin{array}{l}95 \% \text { Confidence } \\
\text { Interval for Mean }\end{array}$} & \multirow{2}{*}{$\begin{array}{c}\text { Minmu } \\
\mathrm{m}\end{array}$} & \multirow{2}{*}{$\begin{array}{c}\text { Maximu } \\
\mathrm{m}\end{array}$} \\
\hline & & & & & $\begin{array}{l}\text { Lower } \\
\text { Bound }\end{array}$ & $\begin{array}{l}\text { Upper } \\
\text { Bound }\end{array}$ & & \\
\hline $\operatorname{Jam} 8$ & 30 & 66.26 & 1.635 & .298 & 65.65 & 66.87 & 64 & 71 \\
\hline $\begin{array}{c}\text { Jam } \\
10\end{array}$ & 30 & 62.79 & 2.622 & .479 & 61.81 & 63.77 & 57 & 68 \\
\hline $\begin{array}{c}\text { Jam } \\
12\end{array}$ & 30 & 60.36 & 3.467 & .633 & 59.06 & 61.65 & 55 & 66 \\
\hline Total & 90 & 63.14 & 3.600 & .379 & 62.38 & 63.89 & 55 & 71 \\
\hline
\end{tabular}

Dari tabel di atas dapat diterangkan hasil sebagai berikut: Rata-rata nilai kebisingan Jam 8 Wite sebesar 66,26 dB, sedangkan rata-rata nilai kebisingan Jam 10 Wite sebesar $62,79 \mathrm{~dB}$ dan rata-rata nilai kebisingan Jam 12 Wite sebesar 60,36 dB.

Dengan demikian kebisingan yang tertinggi terjadi pada Jam 8 Wite sebesar 66,26 $\mathrm{dB}$ dengan nilai kebisingan minimum (terendah) adalah $64 \mathrm{~B}$ sedang dengan nilai kebisingan maksimum (tertinggi) adalah $71 \mathrm{~dB}$.

Tabel 4. Test of Homogeneity of Variances

Kebisingan

\begin{tabular}{|c|c|c|c|}
\hline $\begin{array}{c}\text { Levene } \\
\text { Statistic }\end{array}$ & df1 & df2 & Sig. \\
\hline 10.185 & 2 & 87 & .000 \\
\hline
\end{tabular}

Berdasarkan output SPSS nilai levene statistic sebesar 10.185 dengan signifikansi atau probabilitas (sig) 0.000. Sehingga nilai kebisingan pada jam 8, jam 10 dan jam 12 mempunyai nilai tingkat kebisingan yang tidak homogen atau nilai tingkat kebisingan yang berbeda, hal ini karena nilai sig. $0,000<0,05$.

\section{Tabel 5. Hasil ANOVA Output SPSS 23}

ANOVA

Kebisingan

\begin{tabular}{|c|c|c|c|c|c|}
\hline & $\begin{array}{c}\text { Sum of } \\
\text { Squares }\end{array}$ & df & $\begin{array}{c}\text { Mean } \\
\text { Square }\end{array}$ & F & Sig. \\
\hline Between Groups & 528.045 & 2 & 264.022 & 36.730 & .000 \\
Within Groups & 625.379 & 87 & 7.188 & & \\
Total & 1153.424 & 89 & & & \\
\hline
\end{tabular}

Hasil uji beda menggunakan SPSS 23.0 dapat dilihat nilai (sig) 0.000. Karena nilai sig. 0,000<0,05 yang berarti bahwa, nilai kebisingan pada jam 8, jam 10 dan jam 12 mempunyai nilai tingkat kebisingan yang berbeda secara signifikan.

Tabel 6. Multiple Comparisons Output SPSS 23

\section{Multiple Comparisons}

Dependent Variable: Kebisingan 
Tukey HSD

\begin{tabular}{|ll|r|r|r|r|r|}
\hline \multirow{2}{*}{$\begin{array}{l}\text { (I) Jam } \\
\text { (J) Jam }\end{array}$} & $\begin{array}{c}\text { Mean } \\
\text { Difference } \\
\text { (I-J) }\end{array}$ & \multirow{2}{*}{$\begin{array}{c}\text { Std. } \\
\text { Error }\end{array}$} & \multirow{2}{*}{ Sig. } & \multicolumn{2}{|c|}{$\begin{array}{c}\text { L5\% Confidence Interval } \\
\text { Bound }\end{array}$} & $\begin{array}{c}\text { Upper } \\
\text { Bound }\end{array}$ \\
\hline Jam 8 & Jam 10 & $3.467^{*}$ & .692 & .000 & 1.82 & 5.12 \\
& Jam 12 & $5.903^{*}$ & .692 & .000 & 4.25 & 7.55 \\
\hline Jam 10 & Jam 8 & $-3.467^{*}$ & .692 & .000 & -5.12 & -1.82 \\
& Jam 12 & $2.437^{*}$ & .692 & .002 & .79 & 4.09 \\
\hline Jam 12 & Jam 8 & $-5.903^{*}$ & .692 & .000 & -7.55 & -4.25 \\
& Jam 10 & $-2.437^{*}$ & .692 & .002 & -4.09 & -.79 \\
\hline
\end{tabular}

*. The mean difference is significant at the 0.05 level.

Pada tabel ini adalah untuk mengetahui uji beda kebisingan pada masing-masing jam yang berbeda. Hasil dari pengukuran jam 08.00 dibandingkan dengan jam 10.00 Wite mempunyai nilai rata-rata berbeda sebesar 3.467 pada taraf kepercayaan $95 \%$ dengan hasil beda batas bawah sebesar 1.82 dan beda batas atas sebesar 5.12. Hasil penelitian menunjukan tingkat kebisingan jam 08.00 dengan jam 10.00 Wite berbeda, ini terbukti dari nilai .sig $0,000<0,05$.

Hasil dari pengukuran pada jam 08.00 dibandingkan dengan jam 12.00 Wite mempunyai nilai rata-rata berbeda sebesar 5.903 pada taraf kepercayaan $95 \%$ dengan hasil beda batas bawah sebesar 4.25 dan beda batas atas sebesar 7.55. Hasil penelitian menunjukan tingkat kebisingan jam 08.00 dengan jam 12.00 Wite berbeda, ini terbukti dari nilai .sig $0,000<0,05$.

Tabel 7. Uji Tukey HSD pada Kebisingan

Tukey HSD ${ }^{\text {a }}$

\begin{tabular}{|l|r|c|c|c|}
\hline \multirow{2}{*}{ Jam } & \multirow{2}{*}{$\mathrm{N}$} & \multicolumn{3}{|c|}{ Subset for alpha $=0.05$} \\
\cline { 3 - 5 } & 30 & 60.36 & & \multicolumn{1}{c|}{3} \\
\hline Jam 12 & 30 & & 62.79 & \\
Jam 10 & 30 & & & 66.26 \\
Jam 8 & 30 & 1.000 & 1.000 & 1.000 \\
Sig. & & & \\
\hline
\end{tabular}

Means for groups in homogeneous subsets are

displayed.

a. Uses Harmonic Mean Sample Size $=30.000$.

Apabila output atau hasil sebelumnya digunakan untuk mencari variabel mana yang mempunyai perbedaan mean, maka output Homogeneous Subsets digunakan untuk mengetahui sampel / variabel mana yang mempunyai perbedaan yang tidak terlalu signifikan.

Caranya adalah dengan memperhatikan kolom Subset. Pada tabel diatas, kolom subset 1, 2 dan 3 tidak ada variabel satu kolom, ini berarti mean tingkat kebisingan pada Jam 08.00 Wite, Jam 10.00 Wite, dan Jam 12.00 Wite memiliki perbedaan yang signifikan.

\section{KESIMPULAN}

Simpulan dari hasil penelitian menunjukan adanya perbedaan yang signifikan pada taraf kebisingan yang berbeda di jam 08.00, 10.00, dan 12.00 Wite. Taraf kebisingan di 
SDN Melayu 2 Banjarmasin secara umum sudah melewati batas ambang yang ditetapkan sebesar $55 \mathrm{~dB}$. Taraf kebisingan tertinggi terjadi pada jam 08.00 Wite dengan rata-rata $66,26 \mathrm{~dB}$, disusul pada jam 10.00 Wite dengan rata-rata $62,79 \mathrm{~dB}$, dan taraf kebisingan terendah terjadi pada jam 12.00 Wite dengan nilai rata-rata sebesar 60,36 dB.

\section{DAFTAR PUSTAKA}

Arikunto, Suharsimi. 2014. Prosedur Penelitian: Suatu Pendekatan Praktik. Jakarta: Rineka Cipta.

Chandra, Budiman. 2014. Pengantar Kesehatan Lingkungan. Jakarta: EGC.

Halil Amwal, Yanis Amel, Noer Mustafa. (2015). Pengaruh kebisingan lalu lintas terhadap konsentrasi belajar siswa SMPN 1 Padang. Jurnal Ilmiah Vol. 4, No.1, 54.

Ibnu, Sabta Nur. 2019. Pengaruh Kebisingan Lalu Lintas Terhadap Tingkat Ketergangguan Individu Siswa. Jurnal Manajemen Rekayasa. Vol. 1 No 2 Oktober 2019.

Justian, Alex. 2012. Analisis pengaruh kebisingan terhadap performa siswa sekolah Dasar di ruang kelas. Fak. Teknik UI, Skripsi.

Latifah. 2019. Pola Komunikasi Interpersonal Guru PAI Terhadap Keberhasilan Belajar Siswa Pada Mi Assalam Martapura Dan Sd Muhammadiyah Martapura Kabupaten Banjar. Jurnal Terapung: Ilmu-Ilmu Sosial, e-ISSN: 2656-2928. Vol. 1 No. 2 DOI: http://dx.doi.org/10.31602/jt.v1i2.2556

Marisdayana et.al, 2016. Hubungan Intensitas Paparan Bising Dan Masa Kerja Dengan Gangguan Pendengaran Pada Karyawan PT. X. (Online), Vol. JKLI 15 (1), 2016, (http://ejournal.undip.ac.id/index.php/jkli, diakses 7 Juli 2020).

Ngalimun. 2014. Strategi dan Model Pembelajaran. Yogyakarta: Aswaja Pressindo

Riduwan, 2010. Metode \& Teknik Menyusun Tesis. Bandung: ALFABETA.

Sudijono, Anas, 2010. Pengantar Statistik Pendidikan. Jakarta: PT Raja Grafindo Persada. Cetakan ke-22.

Sugiyono. 2017. Metode Penelitian Kombinasi (Mixed Methods). Bandung: Alfabeta. 